\title{
Long-Term Specification of AMPA Receptor Properties after Synapse Formation
}

\author{
J. Josh Lawrence ${ }^{1}$ and Laurence 0 . Trussell ${ }^{2}$ \\ ${ }^{1}$ Neuroscience Training Program and 2Department of Physiology, University of Wisconsin-Madison, \\ Madison Wisconsin 53711
}

\begin{abstract}
AMPA receptors expressed at auditory nerve synapses in the mammalian and avian cochlear nuclei display exceptionally rapid channel gating, an adaptation well suited for acoustic processing. We examined whether cellular interactions during development might determine the subunit composition of these receptors. After synapse formation in the avian nucleus magnocellularis (nMag) in vivo, the rate of receptor desensitization increased threefold, sensitivity to channel block by polyamines increased, and sensitivity to cyclothiazide, an inhibitor of de-
\end{abstract}

sensitization, increased, indicating a reduction in glutamate receptor subunit 2 and of flip splice variants. This phenotypic switch was prevented, but not reversed, by isolating nMag neurons in a cell-culture environment. We propose that the switch in receptor kinetics is an outcome of cellular interactions during a critical period that result in the long-term determination of receptor phenotype.

Key words: cochlear nucleus; auditory nerve; glutamate; development; ion channels; avian
The activation of AMPA receptors by synaptically released glutamate mediates rapid excitatory transmission in diverse neural pathways in the CNS (Collingridge and Lester, 1989). The assembly of glutamate receptor subunits 1-4 (GluR1-GluR4) into a heteromultimeric complex, as well as the editing and alternative splicing of the subunit RNA, generates many possible receptor isoforms for use at a given synapse (Borges and Dingledine, 1998). The molecular diversity of these receptors underlies their functional diversity and is an essential element for tailoring synaptic transmission on a pathway- or synapse-specific basis (Trussell, 1998).

Although the molecular refinement of neurons is key to the coding of information in complex neural systems, there is relatively little known about the cellular mechanisms that direct the cell-specific expression of AMPA receptor subunits and their processing. One common theme is the developmental control of expression of different subtypes of receptor, often through the action of presynaptic signals. Such control has been posited for acetylcholine, glutamate, glycine, and GABA receptors (Monyer et al., 1991; Carmignoto and Vicini, 1992; Farrant et al., 1994; Tia et al., 1996; Fischbach and Rosen, 1997; Ozaki et al., 1997). Subunits and splice variants of AMPA receptors also differ with brain region and over development. However, there remains little evidence linking specific cellular interactions in vivo to the expression of particular AMPA receptor isoforms. Factors limiting such analyses include heterogeneity of cell types within a given brain region, the diverse sources of excitation for any one cell type, the large number of synaptic contacts, and the broad time

Received June 14, 1999; revised March 21, 2000; accepted April 18, 2000.

This work was supported by National Institutes of Health Grant DC02004. We are grateful to Stephan Brenowitz, Stephanie Gardner, Donata Oertel, Indira Raman, Rostislav Turecek, and Ken Tovar for thoughtful comments on this manuscript.

Correspondence should be addressed to Dr. L. O. Trussell at his present address: Auditory Neuroscience, L-335A, Oregon Health Sciences University, 3181 SW Sam Jackson Park Road, Portland, OR 97201. E-mail: trussell@ohsu.edu.

Dr. Lawrence's present address: Unit on Cellular and Synaptic Physiology, Laboratory of Cellular and Molecular Neurobiology, National Institute of Child Health and Human Development, National Institutes of Health, Bethesda, MD 20892.

Copyright (c) 2000 Society for Neuroscience $0270-6474 / 00 / 204864-07 \$ 15.00 / 0$ period encompassed by synaptogenesis. Moreover, it has not been possible to separate intrinsic and determinative programs of gene expression. Finally, it is unclear whether such determinative cellular interactions are transitory or whether they must continue throughout the life of the synapse.

Neurons of the avian cochlear nucleus magnocellularis (nMag), which contain the avian homologs of mammalian spherical bushy cells, offer a unique opportunity for exploring the immediate consequences of innervation on the expression of AMPA receptors in vivo. The total excitatory innervation consists of only two to three auditory nerve axons that form morphological and functional synaptic contact between embryonic days 10 (E10) and E11 (Rubel and Parks, 1988). During the period after innervation, the neurons undergo profound synaptic rearrangements that result in the formation of somatic end-bulb synapses by E16. Like many auditory brainstem nuclei, the passaging of high-frequency, well timed signals is mediated by synapses that express AMPA receptors having unusually brief kinetics of channel gating (Raman et al., 1994). We have taken advantage of this well described preparation to examine the control of the fast-acting AMPA receptors expressed in nMag neurons. Our results indicate that the channel gating properties and pharmacological sensitivity of AMPA receptors change soon after innervation. Neurons cultured before this change took place did not acquire fast-desensitizing AMPA receptors. In contrast, once this transition in expression took place, cells maintained fast-desensitizing receptors even after 1 month in low-density cultures. Thus, the mature complement of AMPA receptors may be permanently specified by cellular interactions that take place during development.

\section{MATERIALS AND METHODS}

Slice recordings. Coronal, $100-350-\mu \mathrm{m}$-thick slices containing nMag were made from chick embryos as described previously (Zhang and Trussell, 1994). Slices were transferred to a bath chamber perfused with room temperature, oxygenated saline [containing (in mM): $140 \mathrm{NaCl}, 20$ glucose, $10 \mathrm{HEPES}, 5 \mathrm{KCl}, 3 \mathrm{CaCl}_{2}$, and $1 \mathrm{MgCl}_{2}$ ] flowing at $5 \mathrm{ml} / \mathrm{min}$. Neurons were visualized with an upright microscope using Nomarski optics and a $40 \times$ water-immersion objective. Intracellular solution contained (in mM): $70 \mathrm{Cs}_{2} \mathrm{SO}_{4}, 85$ sucrose, $4 \mathrm{NaCl}, 1 \mathrm{MgCl}_{2}, 10 \mathrm{HEPES}$, and 
5 BAPTA, buffered to $\mathrm{pH} 7.3$ with $\mathrm{CsOH}$. Resistances of patch pipettes ranged from 3 to $5 \mathrm{M} \Omega$.

Outside-out patches were excised from nMag neurons on the surface of the slice. Action potentials were elicited in whole-cell mode just before patch excision to confirm that the recordings were from neurons and not glial cells. For rapid application of $10 \mathrm{~mm}$ glutamate to patches, a theta pipette attached to a piezoelectric translator was used as described previously (Raman et al., 1994), except that solution delivery through the theta pipette was driven by nitrogen pressure. Control and glutamate solutions contained normal Ringer's solution with $200 \mu \mathrm{M}$ D,L-2-amino5-phosphonovaleric acid and $10 \mu \mathrm{M}$ 7-chlorokynurenic acid, so that no NMDA receptors would be activated during glutamate applications. The $10-90 \%$ solution exchange time was typically $\sim 150 \mu \mathrm{sec}$, as measured in each recording using the junction potential between Ringer's solution and 10\% Ringer's solution (Jonas, 1995). An example of the exchange time is shown in Figure 1. Electrophysiological data were Bessel filtered (Frequency Devices, Haverhill, MA) at $10 \mathrm{kHz}$ and digitized at 20-50 $\mathrm{kHz}$ with pClamp software (Axon Instruments, Foster City, CA).

Preparation of nMag cultures. nMag neurons were enzymatically dissociated from tissue chunks microdissected from brain slices as described previously (Raman et al., 1994), with minor modifications for sterile conditions. Briefly, brain slices prepared as above were soaked in an oxygenated solution containing papain (Worthington, Freehold, NJ) for 10-20 min and then rinsed. nMag was then dissected out of each slice using fine tungsten needles, and the tissue chunks were gently triturated. After dissociation, aliquots of the cell suspension were seeded onto poly-D-lysine (Sigma, St. Louis, MO)-laminin (Worthington)-coated glass coverslips on which a confluent monolayer of flat astrocytes had been established. Cultures were kept at $37^{\circ} \mathrm{C}$ and $5 \% \mathrm{CO}_{2}$ in MEM-based media containing $10 \%$ fetal bovine serum (Sigma), $10 \%$ horse serum (Atlanta Biological), $20 \mathrm{~mm}$ glucose, and $1 \%$ penicillinstreptomycin (Life Technologies, Gaithersburg, MD). After $24 \mathrm{hr}$, the media was changed to one that replaced fetal bovine serum with horse serum. Cells for acute recordings were plated onto poly-D-lysine-coated coverslips without glia and used for up to $2 \mathrm{hr}$ after plating.

Retrograde labeling of nMag. A freshly isolated brainstem was transferred to a dish containing oxygenated saline and pinned ventricle-side up with insect pins. A pipette of $\sim 10-20 \mu \mathrm{m}$ tip diameter containing 10-40\% 3-10 kDa molecular weight tetramethylrhodamine (TMR) dextran or biotinylated dextran (Molecular Probes, Eugene, OR) and 5-10\% methyl green dissolved in $0.1 \mathrm{M}$ phosphate buffer, adjusted to $\mathrm{pH} 2$ with $\mathrm{HCl}$, was inserted into the ipsilateral brainstem at the level of nMag and nucleus laminaris. Dye was injected until the methyl green was visible in the tissue by eye. The intact brainstem was then incubated at $37-40^{\circ} \mathrm{C}$ for $30-60 \mathrm{~min}$ and continually oxygenated. nMag neurons on the uninjected side were then prepared for culture as described.

Statistical significance was determined by two-tailed $t$ test, and errors are given as SEM.

\section{RESULTS}

\section{Developmental control of time course of desensitization}

The time course of desensitization of AMPA receptors, which varies markedly with subunit composition (Mosbacher et al., 1994), was used to probe developmental changes in AMPA receptors. Application of $10 \mathrm{~mm}$ glutamate for $100 \mathrm{msec}$ resulted in activation and nearly complete desensitization of AMPA receptors (Raman and Trussell, 1992; Trussell et al., 1993) (see Materials and Methods). The time course of desensitization, measured by fitting the onset of desensitization with a single exponential, was determined for patches excised from nMag neurons in brain slices at various stages of development. In Figure 1, the time constant of desensitization $\left(\tau_{\mathrm{des}}\right)$ is plotted versus embryonic age and shows a progressive speeding up of desensitization with development. For example, at E9, $\tau_{\mathrm{des}}$ was $4.45 \pm 0.80 \mathrm{msec}(n=$ $6)$, whereas at E18, $\tau_{\text {des }}$ was $1.56 \pm 0.12 \mathrm{msec}(n=8$, significance at $p<0.002$ ). The inset shows representative glutamate-activated currents from patches excised from somata at E11, E13.5, and E18. The deactivation time constant, measured from the decay of responses after $1 \mathrm{msec}$ pulses of glutamate, did not differ signif-

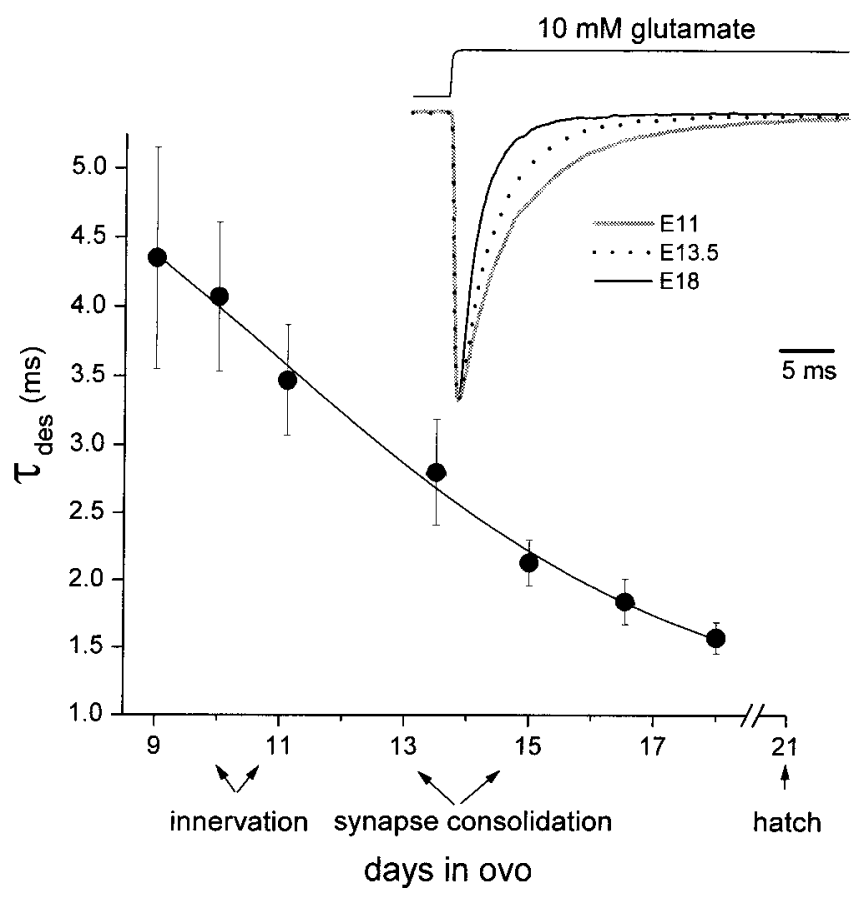

Figure 1. Developmental acceleration in AMPA receptor desensitization kinetics. Single exponential time constant of desensitization $\left(\tau_{\mathrm{des}}\right)$ versus embryonic age $(E)$ of development. Glutamate $(10 \mathrm{~mm})$ was rapidly applied to patches excised from nMag neurons in slices at various stages of development. Shown below the axis are major developmental events during this time period. From left, points are mean \pm SEM of $6,3,9,10$, 8,11 , and 8 patches. Horizontal bars denote variation in developmental time points pooled for each data point. Inset, Scaled representative current traces excised from neurons at E11 (gray), E13.5 (dotted), and E18 (black). Traces are averages of 10-30 events. Time course of exchange (junction potential change) is illustrated above the current traces.

icantly over this time span (E9-E12, $1.02 \pm 0.3 \mathrm{msec}, n=13$; E17-E18, $0.67 \pm 0.13 \mathrm{msec}, n=13 ; p=0.29)$. Similarly, the $10-90 \%$ rise times of glutamate responses were unchanged over this period (E10-E11, $0.26 \pm 0.06 \mathrm{msec}, n=10$; E17-E18, $0.21 \pm$ $0.06 \mathrm{msec}, n=14 ; p=0.57)$. The data indicate that, in the time period immediately after innervation by the auditory nerve, fastdesensitizing AMPA receptors replaced receptors having slower channel kinetics.

\section{Spermine block of AMPA receptors is greatest in older neurons}

Intracellular spermine blocks AMPA receptor-channels according to the fractional contribution of GluR2 to the receptor complex, such that reduction in GluR2 content increases susceptibility to channel block (Washburn et al., 1997). We examined channel block by spermine in patches isolated from E11 and E18 embryos. AMPA receptor-mediated currents obtained at holding potentials from -75 to $+60 \mathrm{mV}$ are shown in Figure 2, $A$ and $B$. All data were recorded in the continuous presence of $1 \mathrm{~mm}$ intracellular spermine. Sixty micromolar extracellular cyclothiazide (CTZ) was included to reduce desensitization during the response. Figure $2 C$ shows overlaid current-voltage ( $I-V)$ relationships and illustrates that, at positive potentials, there was less inward rectification in E11 than in E18 neurons at positive potentials. The extent of rectification was summarized in Figure $2 D$ by using a rectification index [the ratio of conductance at $+30 \mathrm{mV}$ to conductance at $-60 \mathrm{mV}$ (Kamboj et al., 1995)]. In accordance 
Figure 2. Developmental control of subunit composition indicated by changes in spermine sensitivity. $A, B$, Families of AMPA receptor-mediated currents at potentials from -75 to $+60 \mathrm{mV}$ in $15 \mathrm{mV}$ increments in patches from E11 and E18 neurons. All patches were in the continuous presence of $1 \mathrm{~mm}$ intracellular spermine and $60 \mu \mathrm{M}$ extracellular CTZ. Slowed deactivation in $A$ was inconsistently observed. $C$, Currentvoltage relationship showing, that at positive potentials, there is less inward rectification in E11 (open circles) than in E18 (filled circles) neurons. Currents were normalized to the current amplitude at $-60 \mathrm{mV}$. $D$, Rectification index, as defined by the ratio of conductance $(G)$ at $+30 \mathrm{mV}$ relative to conductance at $-60 \mathrm{mV}$ for both E11 $(n=4)$ and E18 $(n=5)$ neurons. $I-V$ relationships in patches from E18 neurons (gray bar) are slightly outwardly rectifying (rectification index $>1$ ) in the absence of intracellular spermine $(n=3)$. * indicates rectification ratio significantly less at E18 than E11 $(p<$ $0.001)$. E11 and spermine-free control data also differed significantly $(p<0.01)$.
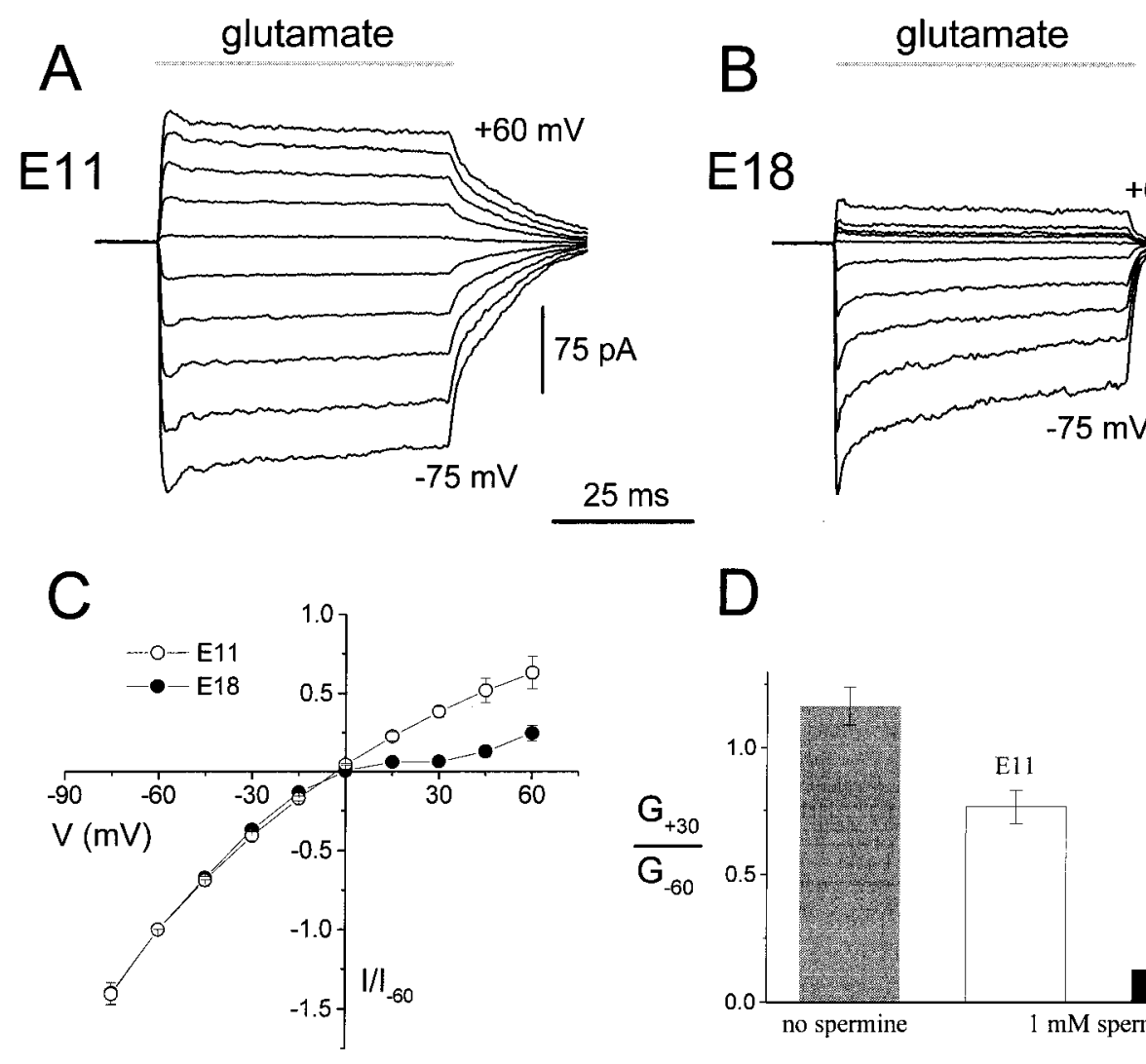

E18

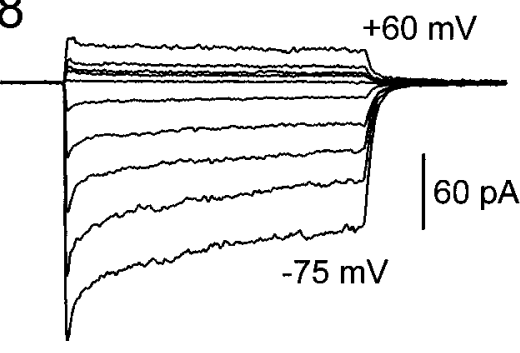

C

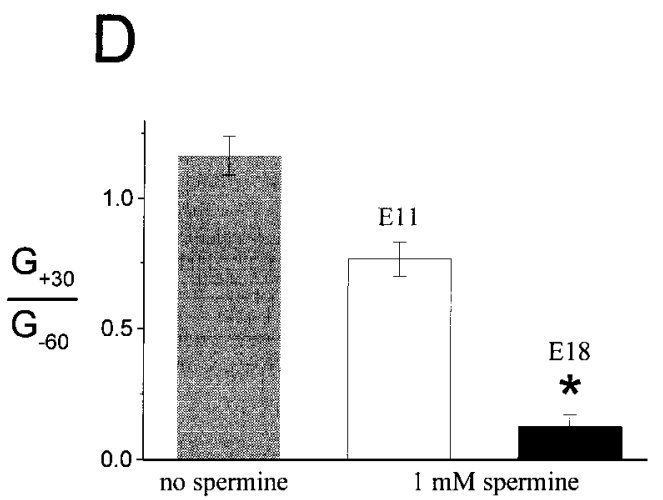

with previous results (Raman and Trussell, 1995), the $I-V$ relationship for receptors from E18 cells (gray bar) is slightly outwardly rectifying (rectification index above 1) in the absence of intracellular spermine. In the presence of spermine, the rectification index was $<1$ for both E11 and E18 but significantly smaller for the E18 neurons $(p<0.001)$, indicating a decrease in the expression of GluR2 during the period from E11 to E18.

\section{Reduced expression of flip isoforms}

With the exception of the GluR1 subunit (which is weakly expressed in auditory brainstem nuclei; see Discussion), AMPA receptors composed of flop splice variants have faster desensitization that those containing flip subunits (Mosbacher et al., 1994; Koike et al., 2000). We tested whether a shift in the relative proportion of flip- versus flop-containing subunits could account for the developmental changes in AMPA receptor kinetics by measuring the extent of desensitization in the presence of CTZ. As a result of their higher affinity for CTZ, flip receptors are more resistant to desensitization in the presence of CTZ than are flop receptors (Partin et al., 1995; Fleck et al., 1996). Long pulses (2 sec) of $10 \mathrm{~mm}$ glutamate were delivered in the continued presence of $60 \mu \mathrm{M}$ CTZ. The extent of desensitization was expressed as the steady-state/peak current. Of 19 patches taken from either E11 or E17 neurons, all but three desensitized by $>75 \%$, indicating the presence of flop subunits. The remaining three desensitized by $0-30 \%$ and were excluded from further analysis. Nevertheless, as illustrated in Figure 3, $A$ and $B$, desensitization was significantly stronger for receptors in cells from older animals. These data suggest that flip subunits become less prevalent during development.

\section{Factors in the cellular environment drive changes in receptor phenotype}

To determine whether cellular interactions within nMag are required for the acquisition of fast-desensitizing AMPA receptors, we studied the desensitization time course of isolated neurons maintained in vitro for varying periods of time. Because this experiment requires microdissection of neurons and treatment with proteolytic enzymes (see Materials and Methods), which

A
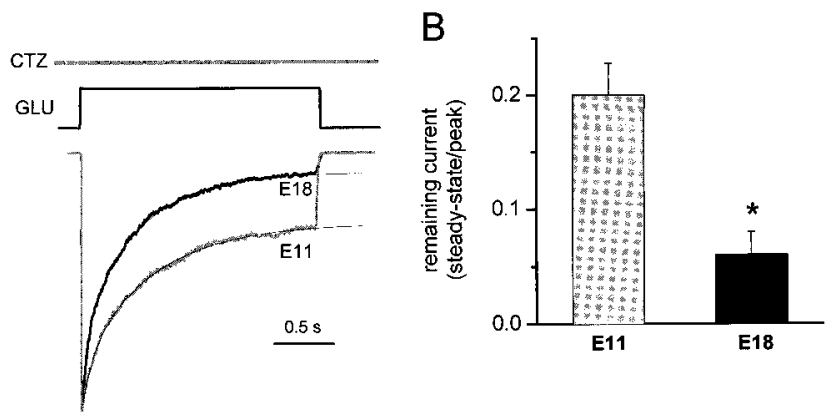

Figure 3. Developmental changes in flip-flop splice variants indicated by changes in effectiveness of cyclothiazide. $A$, Long pulses $(2 \mathrm{sec})$ of $10 \mathrm{~mm}$ glutamate in the continued presence of $60 \mu \mathrm{M}$ CTZ show marked desensitization in E11 (gray trace) and E18 (black trace) patches. Traces scaled to same peak value. Double-exponential fits to the traces with the following parameters are shown: E11, $\tau_{\text {fast }} 86 \mathrm{msec}, \tau_{\text {slow }} 588 \mathrm{msec}, 28 \%$ fast phase, $27 \%$ steady-state current; E18, $\tau_{\text {fast }} 51 \mathrm{msec}, \tau_{\text {slow }} 462 \mathrm{msec}, 38 \%$ fast phase, $7 \%$ steady-state current. $B$, The current remaining after desensitization, measured as steady-state/peak ratio in which steady-state current was obtained from best single- or double-exponential fits to the traces during onset of desensitization. $n=5$ and 11 patches for E11 and E18, respectively. $* p<0.05$ indicates significant difference. 


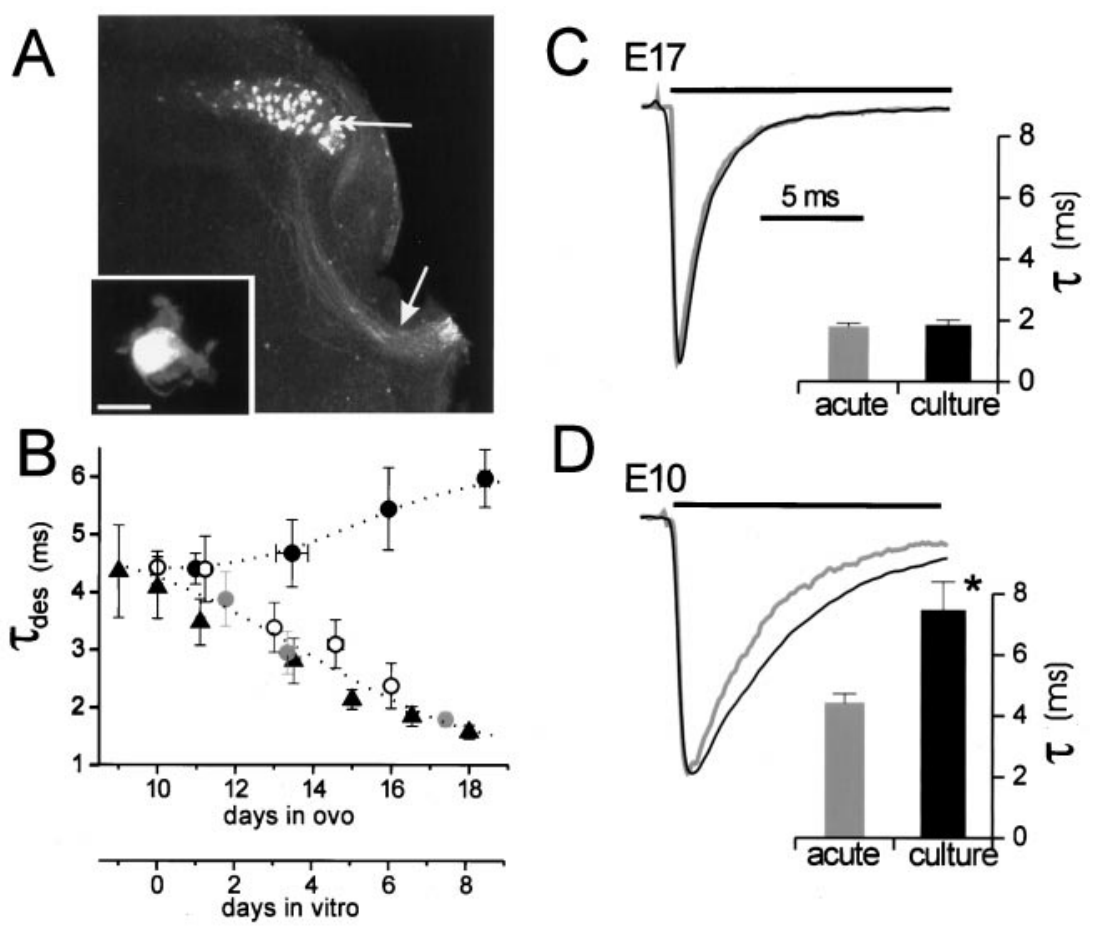

Figure 4. Culture environment arrests the developmental switch to fast AMPA receptor kinetics. $A$, Fluorescent image of contralateral (uninjected) side of slice after retrograde labeling of nMag neurons with TMR. Arrow, Labeled fibers in dorsal acoustic commissure. Double arrow, Labeled nMAG cell bodies in situ. Inset, Representative fluorescent E11 neuron retrogradely labeled and acutely dissociated. Scale bar, $10 \mu \mathrm{m}$. B, AMPA receptor desensitization time constant from neurons in slices ( filled triangles; data from Fig. 1), acutely dissociated TMR-labeled neurons (open circles; $n=3-9$ cells), unlabeled acutely dissociated neurons ( gray filled circles; $n=8-9$ ), and neurons cultured from E10 embryos (black filled circles; $n=9-16$ ). $C$, Representative scaled traces of desensitizing currents in patches from E17 neurons either acutely dissociated (gray trace) or grown for 14-16 d in culture (black trace). Ten millimolar glutamate was applied during the time period marked by the horizontal bar. Inset shows average desensitization time constants of acutely dissociated $(n=10)$ or cultured E17 $(n=22)$ neurons. Time constants were not significantly different $(p=0.49)$. $D$, Scaled traces from E10 neurons either acutely dissociated (gray trace) or grown for 14-16 d in culture (black trace). Inset shows average desensitization time constants of acutely dissociated $(n=6)$ or cultured E10 $(n=20)$ neurons. ${ }^{*} p<0.05$ indicates significance. might alter receptors (Allen et al., 1988), we first showed that enzymatically isolated nMag neurons still retain normal channel gating kinetics. In initial experiments, nMag was retrogradely labeled with a TMR-dextran conjugate before enzymatic isolation (see Materials and Methods), and fluorescent neurons in the dissociate were selected for patch-clamp analysis. Figure $4 A$ shows fluorescently labeled E11 nMag neurons in a slice before enzymatic treatment and an enzymatically isolated E11 neuron (inset). Cells taken from animals younger than E15-E16 generally had somatic protrusions and dendrites characteristic of immature nMag (Jhaveri and Morest, 1982). In Figure 4B, the open circles illustrate the time constant of desensitization measured in acutely isolated, labeled neurons isolated from animals of different age. For comparison, the time constants measured in brain slices ( filled triangles) are also shown. In Figure $4 B$, the gray filled circles show three points in which time constants were measured in neurons from unlabeled nMag dissections. These values were indistinguishable from both labeled neurons and neurons in slices for these stages of development, indicating that most or all of the cells in the dissociate were nMag neurons.

Having demonstrated the isolation of nMag neurons with normal receptor properties, E10 neurons were then isolated and grown in low-density cell culture for varying periods of time (see Materials and Methods), and the desensitization rate of their AMPA receptors was assayed. The average time constant of desensitization in E10 neurons after $1 \mathrm{~d}$ in vitro was indistinguishable from that of E10 acutely dissociated neurons $(p=0.94)$. Unlike the acceleration of desensitization observed in vivo, the time constant of desensitization for neurons isolated at E10 changed marginally over the first $7.5 \mathrm{~d}$ in vitro (Fig. $4 B$, black filled circles). For example, the time constant was $4.4 \pm 0.3 \mathrm{msec}(n=$ $6)$ in freshly isolated E10 cells and $6.0 \pm 0.5 \mathrm{msec}(n=16)$ in E10 cells cultured for $8.5 \mathrm{~d}(p=0.07)$. These results suggest that, in the cell-culture environment, young neurons are not exposed to signals that direct expression of fast-gating subtypes of AMPA receptor.
An alternative model, however, is that the cell-culture environment does not remove an in vivo signal, but itself imposes a "slow" phenotype on AMPA receptors, as suggested by the slight but insignificant slowing of desensitization over $8 \mathrm{~d}$ in vitro and by the documented effects of culture conditions of glutamate receptor expression (see Discussion). To test this alternative more explicitly, we contrasted the kinetics of desensitization in cells isolated from E10 and E17 animals and maintained in culture for over 2 weeks. Remarkably, desensitization time constants in neurons cultured from E17 animals did not become slower and indeed were virtually unchanged, even after $14-31 \mathrm{~d}$ in culture (Fig. $4 C$ ). In contrast, E10 neurons grown for 14-16 d exhibited slightly slower desensitization rates, with a mean value significantly longer than the E10 cells in vivo $(p<0.05)$ (Fig. $4 D)$. Thus, although the culture environment may cause a slowing of receptor kinetics, only the younger cells responded to such an influence; once the mature kinetic phenotype developed, it was stable even when cells were removed from their native environment for long periods of time.

\section{Synaptic and extrasynaptic receptors}

Previous studies have suggested that, in some cases, synaptic and extrasynaptic receptors for a given transmitter may be structurally and physiologically different (Li et al., 1998). The present study indicated that the transition from slow to fast-desensitizing AMPA receptors occurs uniformly over the neuron and not separately at synaptic or extrasynaptic regions. We reasoned that if synaptic and extrasynaptic receptors exhibited different rates of desensitization, as might be expected if developmental regulation acted only on synaptic sites, then there should be a strong correlation between response amplitude and channel gating kinetics. The somatic excitatory innervation of nMag neurons occupies $\sim 45 \%$ of the cell body surface (Parks et al., 1990); some fraction of this area consists of postsynaptic, receptor-rich densities, so that in mature cells some patches should have contained extrasynaptic membrane, synaptic membrane, or mixtures of both. 


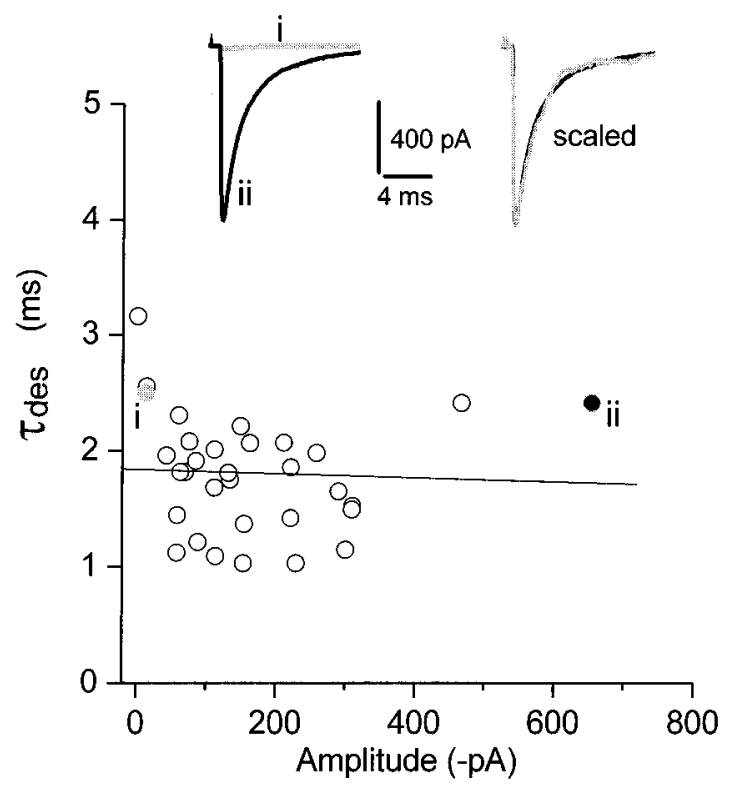

Figure 5. AMPA receptor kinetics are uniform over the entire neuron. Amplitude versus time constant of desensitization for 32 patches from E16-E18 nMag neurons. There was no correlation between patch amplitude and desensitization at these ages, indicating that synaptic and nonsynaptic receptors were indistinguishable in kinetic characteristics. Correlation coefficient is 0.05 . Inset, Representative traces from data points, marked by gray and black circles in main figure, which showed a 50 -fold variation in amplitude (left), are identical in time course when peak responses are normalized (right).

Because AMPA receptors are clustered at synaptic regions (Jones and Baughman, 1991; O’Brien et al., 1998; Trussell et al., 1988), patches with the largest responses probably contained synaptic receptors. Surprisingly, none of our patches from either slices or freshly isolated cells were without glutamate responses, suggesting that extrasynaptic receptors contribute, at least in part, to the smallest responses we obtained. In Figure 5, the time constant of desensitization is plotted against the response amplitude for patches from E16-E18 cells. Assuming a uniform size of patch (see Materials and Methods), the data show that there is no correlation between receptor gating kinetics and receptor density, despite an over 50-fold variation in response amplitude. Thus, it seems likely that the expression of fast AMPA receptors occurs at both synaptic and extrasynaptic regions.

\section{DISCUSSION}

\section{Developmental control of receptor subunits}

Rapidly gating AMPA receptors mediate synaptic transmission in a wide variety of neurons of the central auditory pathway of mammals and birds (Trussell, 1999). Accordingly, several GluR subunits, particularly GluR3 and GluR4, have been identified in mammalian and avian auditory neurons, and glutamate receptor proteins localized to their subsynaptic regions (Hunter et al., 1993; Sato et al., 1993; Petralia et al., 1996; Levin et al., 1997; Wang et al., 1998). In rat medial nucleus of the trapezoid body and the chick nMag, flop splice variants are prominent (Geiger et al., 1995; Ravindranathan et al., 2000). Moreover, calcium permeability measurements and molecular analyses in rat and chick auditory neurons indicate reduced expression of GluR2 (Geiger et al., 1995; Otis et al., 1995; Zhou et al., 1995; Wang et al., 1998; Ravindranathan et al., 2000). The enhancement of spermine sensitivity during development strongly indicates that there is a reduction in the contribution of GluR2 to functional receptors (Washburn et al., 1997). What differences in expression pattern might underlie the slower desensitization observed at earlier developmental stages? The strongest contributor to fast AMPA receptor kinetics is the expression of flop splice variants, as evidenced by the more rapid desensitization in GluR $2_{\text {flop }}-$ GluR4 $_{\text {flop }}$ (Mosbacher et al., 1994; Koike et al., 2000) and the association of slow desensitization with GluR $2_{\text {flip }}$ in vivo (Geiger et al., 1995; Angulo et al., 1997; Gotz et al., 1997). Given the strong influence of these splice variants in determining channel kinetics, the data presented here suggest that a reduction in flip expression is most likely to explain the developmental changes AMPA receptor kinetics observed in nMag.

Target cells of the auditory nerve all produce rapidly gating AMPA receptors and high levels of GluR3 and GluR4 (Hunter et al., 1993; Raman et al., 1994; Wang et al., 1998; Gardner et al., 1999). Even auditory nerve targets such as avian nucleus angularis or mammalian stellate neurons, which may not transmit timing information (and therefore would not be expected to require brief currents), also feature fast-acting receptors (Hunter et al., 1993; Raman et al., 1994; Gardner et al., 1999). Moreover, fusiform cells of the mammalian dorsal cochlear nucleus, which receive excitatory input from both auditory nerve and parallel fibers, express a mixture of subunit types, which are segregated to the different types of synapse, with GluR4-containing receptors restricted to auditory nerve synapses (Rubio and Wenthold, 1997).

Given this background, our results are consistent with the hypothesis that cellular interactions associated with synapse formation by auditory nerve fibers directs the production of AMPA receptors suited for fast transmission. Within days after innervation, the rate of desensitization of AMPA receptors increases, a change that is completely prevented by isolating cells in tissue culture during the same period. Apparently, the consequences of this cellular interaction are irreversible; isolation of cells after receptors kinetics have become fast did not result in the expression of slowly desensitizing receptors, even after 2 weeks in vitro. Based on these studies, we suggest that a consequence of the initial innervation by auditory nerve is the imprinting of a unique profile of coordinated receptor subunit expression. According to this hypothesis, the maintenance of the mature pattern of receptor expression is independent of ongoing transmitter release or electrical activity. Finally, the observation that younger cells in culture acquire slower receptors suggests that the cell-culture environment does indeed alter the pattern of receptor expression (Condorelli et al., 1993; Bessho et al., 1994; Gottmann et al., 1997; Chew and Gallo, 1999). Because older neurons do not respond to such an influence, there may be a "critical period" during which young neurons are able to respond to signals that determine the subtypes of AMPA receptor that a neuron produces.

Changes in receptor subunits are often associated with innervation and developmental maturation of neural circuitry. Synaptic currents in neuromuscular junctions of mammals and Drosophila speed up as synapses mature (Broadie and Bate, 1993; Fischbach and Rosen, 1997). In mammals, this change is caused by neurally induced replacement of $\gamma$ with $\epsilon$ subunits of the muscle nicotinic acetylcholine receptor. Alterations in NMDA, GABA, and glycine receptor composition are observed in various brain regions during early development (Carmignoto and Vicini, 1992; Takahashi et al., 1992, 1996; Monyer et al., 1994; Gottmann et al., 1997; 
Singer et al., 1998). In the hair cell-spiral ganglion cell synapse, receptors labeled by an antibody to GluR2/3 are developmentally downregulated, with compensation by the GluR4 subunit (Knipper et al., 1997). Developmental changes in receptor composition may be mediated by factors released by presynaptic neurons (Fischbach and Rosen, 1997). Indeed, secreted proteins have been shown to cluster or induce expression of glutamate receptors on a subunit-specific basis (Ozaki et al., 1997; O'Brien et al., 1999). It is possible that auditory nerve terminals release substances that act to control expression of AMPA receptor subunits and their alternative splicing.

\section{REFERENCES}

Allen CN, Brady R, Swann J, Hori N, Carpenter DO (1988) $N$-methylD-aspartate (NMDA) receptors are inactivated by trypsin. Brain Res 458:147-150.

Angulo MC, Lambolez B, Audinat E, Hestrin S, Rossier J (1997) Subunit composition, kinetic, and permeation properties of AMPA receptors in single neocortical nonpyramidal cells. J Neurosci 17:6685-6696.

Bessho Y, Nawa H, Nakanishi S (1994) Selective up-regulation of an NMDA receptor subunit mRNA in cultured cerebellar granule cells by $\mathrm{K}(+)$-induced depolarization and NMDA treatment. Neuron 12:87-95.

Borges K, Dingledine R (1998) AMPA receptors: molecular and functional diversity. Prog Brain Res 116:153-170.

Broadie KS, Bate M (1993) Development of the embryonic neuromuscular synapse of Drosophila melanogaster. J Neurosci 13:144-166.

Carmignoto G, Vicini S (1992) Activity-dependent decrease in NMDA receptor responses during development of the visual cortex. Science 258:1007-1011.

Chew L-J, Gallo V (1999) Regulation of ion channel expression in neural cells by hormones and growth factors. Mol Neurobiol 18:175-225.

Collingridge GL, Lester RA (1989) Excitatory amino acid receptors in the vertebrate central nervous system. Pharmacol Rev 41:143-210.

Condorelli DF, Dell'Albani P, Aronica E, Genazzani AA, Casabona G, Corsaro M, Balazs R, Nicoletti F (1993) Growth conditions differentially regulate the expression of alpha-amino- 3-hydroxy-5methylisoxazole-4-propionate (AMPA) receptor subunits in cultured neurons. J Neurochem 61:2133-2139.

Farrant M, Feldmeyer D, Takahashi T, Cull-Candy SG (1994) NMDAreceptor channel diversity in the developing cerebellum. Nature 368:335-339.

Fischbach GD, Rosen KM (1997) ARIA: a neuromuscular junction neuregulin. Annu Rev Neurosci 20:429-458.

Fleck MW, Bahring R, Patneau DK, Mayer ML (1996) AMPA receptor heterogeneity in rat hippocampal neurons revealed by differential sensitivity to cyclothiazide. J Neurophysiol 75:2322-2333.

Gardner SM, Trussell LO, Oertel D (1999) Time course and permeation of synaptic AMPA receptors in cochlear nuclear neurons correlate with input. J Neurosci 19:8721-8729.

Geiger JR, Melcher T, Koh DS, Sakmann B, Seeburg PH, Jonas P, Monyer H (1995) Relative abundance of subunit mRNAs determines gating and $\mathrm{Ca}^{2+}$ permeability of AMPA receptors in principal neurons and interneurons in rat CNS. Neuron 15:193-204.

Gottmann K, Mehrle A, Gisselmann G, Hatt H (1997) Presynaptic control of subunit composition of NMDA receptors mediating synaptic plasticity. J Neurosci 17:2766-2774.

Gotz T, Kraushaar U, Geiger J, Lubke J, Berger T, Jonas P (1997) Functional properties of AMPA and NMDA receptors expressed in identified types of basal ganglia neurons. J Neurosci 17:204-215.

Hunter C, Petralia RS, Vu T, Wenthold RJ (1993) Expression of AMPA-selective glutamate receptor subunits in morphologically defined neurons of the mammalian cochlear nucleus. J Neurosci 13:1932-1946.

Jhaveri S, Morest DK (1982) Sequential alterations of neuronal architecture in nucleus magnocellularis of the developing chicken: a Golgi study. Neuroscience 7:837-853.

Jonas P (1995) Fast application of agonists to isolated membrane patches. In: Single-channel recording, Ed 2 (Sakmann B, Neher E, eds), pp 231-243. New York: Plenum.

Jones KA, Baughman RW (1991) Both NMDA and non-NMDA sub- types of glutamate receptors are concentrated at synapses on cerebral cortical neurons in culture. Neuron 7:593-603.

Kamboj SK, Swanson GT, Cull-Candy SG (1995) Intracellular spermine confers rectification on rat calcium-permeable AMPA and kainate receptors. J Physiol (Lond) 486:297-303.

Knipper M, Kopschall I, Rohbock K, Kopke AKE, Bonk I, Zimmermann U, Zenner H (1997) Transient expression of NMDA receptors during rearrangement of AMPA receptor-expressing fibers in the developing inner ear. Cell Tissue Res 287:23-41.

Koike M, Tsukada S, Tsuzuki K, Kijima H, Ozawa S (2000) Regulation of kinetic properties of GluR2 AMPA receptor channels by alternative splicing. J Neurosci 20:2166-2174.

Levin MD, Kubke MF, Schneider M, Wenthold R, Carr CE (1997) Localization of AMPA-selective glutamate receptors in the auditory brainstem of the barn owl. J Comp Neurol 378:239-253.

Li JH, Wang YH, Wolfe BB, Krueger KE, Corsi L, Stocca G, Vicini S (1998) Developmental changes in localization of NMDA receptor subunits in primary cultures of cortical neurons. Eur J Neurosci 10:1704-1715.

Monyer H, Seeburg PH, Wisden W (1991) Glutamate-operated channels: developmentally early and mature forms arise by alternative splicing. Neuron 6:799-810.

Monyer H, Burnashev N, Laurie DJ, Sakmann B, Seeburg PH (1994) Developmental and regional expression in the rat brain and functional properties of four NMDA receptors. Neuron 12:529-540.

Mosbacher J, Schoepfer R, Monyer H, Burnashev N, Seeburg PH, Ruppersberg JP (1994) A molecular determinant for submillisecond desensitization in glutamate receptors. Science 266:1059-1062.

O’Brien RJ, Lau LF, Huganir RL (1998) Molecular mechanisms of glutamate receptor clustering at excitatory synapses. Curr Opin Neurobiol 8:364-369.

O'Brien RJ, Xu D, Petralia RS, Steward O, Huganir RL, Worley P (1999) Synaptic clustering of AMPA receptors by the extracellular immediateearly gene product Narp. Neuron 23:309-323.

Otis TS, Raman IM, Trussell LO (1995) AMPA receptors with high $\mathrm{Ca}^{2+}$ permeability mediate synaptic transmission in the avian auditory pathway. J Physiol (Lond) 482:309-315.

Ozaki M, Sasner M, Yano R, Lu HS, Buonanno A (1997) Neuregulinbeta induces expression of an NMDA-receptor subunit. Nature 390:691-694.

Parks TN, Taylor DA, Jackson H (1990) Adaptations of synaptic form in an aberrant projection to the avian cochlear nucleus. J Neurosci 10:975-984.

Partin KM, Bowie D, Mayer ML (1995) Structural determinants of allosteric regulation in alternatively spliced AMPA receptors. Neuron 14:833-843.

Petralia RS, Wang YX, Zhao HM, Wenthold RJ (1996) Ionotropic and metabotropic glutamate receptors show unique postsynaptic, presynaptic, and glial localizations in the dorsal cochlear nucleus. J Comp Neurol 372:356-383.

Raman IM, Trussell LO (1992) The kinetics of the response to glutamate and kainate in neurons of the avian cochlear nucleus. Neuron 9:173-186.

Raman IM, Trussell LO (1995) Concentration-jump analysis of voltagedependent conductances activated by glutamate and kainate in neurons of the avian cochlear nucleus. Biophys J 69:1868-1879.

Raman IM, Zhang S, Trussell LO (1994) Pathway-specific variants of AMPA receptors and their contribution to neuronal signaling. J Neurosci 14:4998-5010.

Ravindranathan A, Donevan SD, Sugden SG, Greig A, Rao MS, Parks TN (2000) Contrasting molecular composition and channel properties of AMPA receptors on chick auditory and brainstem motor neurons. J Physiol (Lond) 523:667-684.

Rubel EW, Parks TN (1988) Organization and development of the avian brainstem auditory system. In: Auditory function (Edelman GM, Gall WE, Cowan WM, eds), pp 3-92. Newark, NJ: Wiley.

Rubio ME, Wenthold RJ (1997) Glutamate receptors are selectively targeted to postsynaptic sites in neurons. Neuron 18:939-950.

Sato K, Kiyama H, Tohyama M (1993) The differential expression patterns of messenger RNAs encoding non- $N$-methyl-D-aspartate glutamate receptor subunits (GluR1-4) in the rat brain. Neuroscience 52:515-539.

Singer JH, Talley EM, Bayliss DA, Berger AJ (1998) Development of glycinergic synaptic transmission to rat brain stem motoneurons. J Neurophysiol 80:2608-2620. 
Takahashi T, Momiyama A, Hirai K, Hishinuma F, Akagi H (1992) Functional correlation of fetal and adult forms of glycine receptors with developmental changes in inhibitory synaptic receptor channels. Neuron 9:1155-1161.

Takahashi T, Feldmeyer D, Suzuki N, Onodera K, Cull-Candy SG, Sakimura K, Mishina M (1996) Functional correlation of NMDA receptor epsilon subunits expression with the properties of singlechannel and synaptic currents in the developing cerebellum. J Neurosci 16:4376-4382.

Tia S, Wang JF, Kotchabhakdi N, Vicini S (1996) Developmental changes of inhibitory synaptic currents in cerebellar granule neurons: role of GABA(A) receptor alpha 6 subunit. J Neurosci 16:3630-3640.

Trussell L (1998) Control of time course of glutamatergic synaptic currents. Prog Brain Res 116:59-69.

Trussell LO (1999) Synaptic mechanisms for coding timing in auditory neurons. Annu Rev Physiol 61:477-496.

Trussell LO, Thio LL, Zorumski CF, Fischbach GD (1988) Rapid de- sensitization of glutamate receptors in vertebrate central neurons. Proc Natl Acad Sci USA 85:4562-4566.

Trussell LO, Zhang S, Raman IM (1993) Desensitization of AMPA receptors upon multiquantal neurotransmitter release. Neuron 10:1185-1196.

Wang YX, Wenthold RJ, Ottersen OP, Petralia RS (1998) Endbulb synapses in the anteroventral cochlear nucleus express a specific subset of AMPA-type glutamate receptor subunits. J Neurosci 18:1148-1160.

Washburn MS, Numberger M, Zhang S, Dingledine R (1997) Differential dependence on GluR2 expression of three characteristic features of AMPA receptors. J Neurosci 17:9393-9406.

Zhang S, Trussell LO (1994) Voltage clamp analysis of excitatory synaptic transmission in the avian nucleus magnocellularis. J Physiol (Lond) 480:123-136.

Zhou N, Taylor DA, Parks TN (1995) Cobalt-permeable non-NMDA receptors in developing chick brainstem auditory nuclei. NeuroReport 6:2273-2276. 